\title{
Carnimonas nigrificans gen. nov., sp. nov., a bacterial causative agent for black spot formation on cured meat products
}

\author{
M. Garriga, ${ }^{1}$ M. A. Ehrmann, ${ }^{2}$ J. Arnau, ${ }^{1}$ M. Hugas ${ }^{1}$ and R. F. Vogel ${ }^{2}$
}

Author for correspondence: M. A. Ehrmann. Tel: +49 8161713790 . Fax: +49816171 3327. e-mail:m.ehrmann@1rz.tu-muenchen.de

1 IRTA, Centre de Tecnologia de la Carn, Monells, Girona, Spain

2 Technische Universităt München, Lehrstuhl für Technische Mikrobiologie, 85350 Freising-

Weihenstephan, Germany

\begin{abstract}
Nine different strains, CTCBS1' to CTCBS9, were identified to be the causative agents of black spots on the surface of raw cured meat products. The formation of black spots under aerobic conditions is reproducible upon reinoculation of meat products with any of these strains, indicating that they are the causative agent. The strains were Gram-negative, catalase-positive and obligately aerobic rods. The G+C content of DNA of strain CTCBS1 ${ }^{\top}$ is $56.0 \pm 0.3 \mathrm{~mol} \%$. The content of non-polar main fatty acids were 16:0, 16:1, 18:1 and 19:0 cyc. Its phylogenetic position was elucidated by comparative sequence analysis of the 165 rRNA gene. Overall sequence similarity to other bacteria does not exceed $93.3 \%$. Isolate CTCBS1 ${ }^{\top}$ clustered phylogenetically within the $\gamma$-subclass of the Proteobacteria and is closely related to members of Halomonas (90.5-91.9\%) and to Zymobacter palmae (93.3\%). A genetic homogeneity of the nine strains was demonstrated by M13 random amplified polymorphic DNA-PCR, whereas differentiation from other genera, e.g. Zymobacter and Pseudomonas, could easily be achieved by their chemotaxonomic characteristics. Taxonomic data revealed the status of a separate genus for which the name Carnimonas gen. nov., sp., nov. is proposed. Despite chemotaxonomic and physiological similarities, the new genus is at present not a member of the family Halomonadaceae because of the lack of two out of 15 descriptive 165 rRNA signature sequences. The first member of the new genus is Carnimonas nigrificans. The use of a specific, 165 rRNA-targeted oligonucleotide primer allowed the identification of all nine strains of C. nigrificans in a PCR assay. Toxicological studies showed no pathogenic potential for $C$. nigrificans strain CTCBS1 ${ }^{\top}$ (CECT 4437').
\end{abstract}

Keywords: Carnimonas nigrificans gen. nov., sp. nov., cured meat products

\section{INTRODUCTION}

The browning of foods is a major problem, which can cause deleterious changes in its appearance, texture and flavour, resulting in a shorter shelf life and decreased market value.

The presence of black spots on the surface of food products has been described in connection with miscellaneous organisms of different origin. Some fungal

Abbreviation: RAPD, random amplified polymorphic DNA.

The EMBL accession number for the 16S rDNA sequence reported in this paper is $Y 13299$. species, such as Cladosporium cladosporoides, Cladosporium herbarum, Penicillium hirsutum and Aureobasidium pullulans, develop black-coloured colonies on raw meat stored at $-1{ }^{\circ} \mathrm{C}$ (Gill \& Lowry, 1982). Colletotrichum coccodes (Wallr.) Hughes produces black spot tubers of potato (Read, 1991), whereas Alternaria alternata is the causal agent of black spot disease on mango fruits (Prusky et al., 1993). Within bacteria, pigmentation is a well-known phenomenon. There are some reports on organisms isolated from marine environments belonging mainly to the Proteobacteria, which are capable of forming brown-black colonies. In the case of Alteromonas nigrifaciens, the chemical structure of the dark pigment was identified as an indigoidine-like compound, the production of 
which has already been described for Clavibacter michiganense subsp. insidiosum, formerly Corynebacterium insidiosum (Starr, 1958; Norton \& Jones, 1969). Within the Proteobacteria, there is also a variety of organisms known for pigmentation, e.g. Halomonas subglaciescola (Franzmann et al., 1987), Chromohalobacter (Ventosa et al., 1989) and members of the recently described genus Pseudoalteromonas (Gauthier et al., 1992), which includes both pigmented and nonpigmented species. Chromobacterium produces violacein, which is only produced freely on media containing tryptophan (Sneath, 1984).

The presence of dark spots on the surface of raw cured meat products was first described by Hugas \& Arnau (1987). In 1993, a Gram-negative bacterium was identified as being responsible for a rust-like colour, turning black within a few hours, in cured meat products (Arnau \& Garriga, 1993). The defect was reproduced on minced meat with salt $\left(40 \mathrm{~g} \mathrm{~kg}^{-1}\right)$, dextrose $\left(20 \mathrm{~g} \mathrm{~kg}^{-1}\right)$ and nitrate $\left(0.2 \mathrm{~g} \mathrm{~kg}^{-1}\right)$ after inoculation of an overnight culture of the previously identified strain $\left(\mathrm{CTCBS}^{\mathrm{T}}\right)$. The black spots appeared under aerobic conditions, between 30 and $35^{\circ} \mathrm{C}$ as optimum temperature and in the presence of dextrose, maltose or dextrin. Sodium nitrite and potassium bisulphide were the most efficient among the preservatives assayed in preventing the defect (Arnau \& Garriga, 1993).

This contribution provides physiological data as well as a phylogenetic characterization to clarify the taxonomic position of these organisms. We propose a new genus, the genus Carnimonas gen. nov, containing one species, Carnimonas nigrificans sp. nov., which includes nine different strains.

\section{METHODS}

Bacterial strains and cultivation. Nine strains, CTCBS $1^{\mathrm{T}}$ to CTCBS9, isolated by Arnau \& Garriga in 1993 were investigated. Organisms used as reference strains were from the DSMZ (Deutsche Sammlung für Mikroorganismen und Zellkulturen, Braunschweig, Germany). All organisms were stored at $-80^{\circ} \mathrm{C}$ in glycerol $(20 \%)$ and were cultured routinely at $30^{\circ} \mathrm{C}$ in tryptone soya broth (Difco) supplemented with bacto agar $(1.4 \%)$ depending on the assay.

Physiological and biochemical characterization. Gram staining and determination of oxidase and catalase activities were by standard methods. The presence of endospores was tested using the Schaeffer-Fulton method. The mobility of cells was observed at 1000 -fold magnification (resolution of $0.26 \mu \mathrm{m}$ ) in a phase-contrast microscope. All physiological tests were performed at $30^{\circ} \mathrm{C}$ and incubated for $72 \mathrm{~h}$, unless otherwise stated. API $50 \mathrm{CH}$ strips were inoculated according to the manufacturer's instructions (API System) and analysed after $11 \mathrm{~d}$. Growth in different salt concentrations was carried out for $72 \mathrm{~h}$ in tryptone soya broth supplemented with $\mathrm{NaCl}$ to final concentrations of 5, 7.5 and $10 \%(\mathrm{w} / \mathrm{v})$ respectively. Growth was determined in MacConkey agar, SS agar and cetrimide agar (Difco). Bacto OF basal medium (Difco) was used for the determination of acid production from different carbohydrates added to a final concentration of $1 \%(\mathrm{w} / \mathrm{v})$. Respiratory lipochinones were extracted according to Tindall (1990) and analysed by HPLC as described by Franzmann \& Tindall (1990). The cellular fatty acid composition of strain CTCBS1 ${ }^{\mathrm{T}}$ was determined by GC after the preparation of whole-cell methanolysates (Minnikin et al., 1977). The fatty acid methyl esters were analysed using a Microbial Identification System (MIS; Microbial ID). The relative amount of fatty acids was expressed as a percentage of the total fatty acids. Polar lipids were analysed as described by Franzmann \& Tindall (1990).

DNA isolation. Large-scale genomic DNA isolation was performed according to Marmur (1961). Small amounts of DNA used for PCR were extracted and purified as described by Lewington et al. (1987).

DNA base composition. The $\mathrm{G}+\mathrm{C}$ content of the DNA was determined by the thermal denaturation method using a Gilford 2600 spectrophotometer according to Huss et al. (1983). For the calculation of the $\mathrm{G}+\mathrm{C}$ content, the equation of DeLey (1970) was used and corrected according to the DNA of Escherichia coli strain K-12 (G+C 51.7 mol \%) used as a reference.

Design and evaluation of an rRNA-targeted primer specific for strain CTCBS1 ${ }^{\top}$. The sequence of the oligonucleotide used as a specific primer for strain $\mathrm{CTCBS1}^{\mathrm{T}}$ (bs1) was $5^{\prime}$ TAACGTCCTTCATGCCGG-3' (binding position 469486 in the Escherichia coli numbering system). This primer was checked for its specificity against more than $1000016 \mathrm{~S}$ rRNA sequences by using the probe-checking software provided in the Ribosomal Database Project (Maidak et al., 1996). The sequence of the universal primers 616VII and 630R used for PCR controls were 5'-AGAGTTTGATYMTGGCTCAG-3' and 5'-CAKAAAGGAGGTGATCC- ${ }^{\prime}$. PCR and cycle conditions for the species-specific reaction with primer bs 1 and universal primer $616 \mathrm{~V}$ were as follows: one initial cycle of $94^{\circ} \mathrm{C}$ for $120 \mathrm{~s}$, followed by 32 cycles of $94^{\circ} \mathrm{C}$ for $45 \mathrm{~s}, 50^{\circ} \mathrm{C}$ for $90 \mathrm{~s}$ and $72^{\circ} \mathrm{C}$ for $120 \mathrm{~s}$. The PCR reactions were carried out in an Omnigene thermocycler (Hybaid) in a total volume of $50 \mu \mathrm{l}$. Master mixes were prepared with reaction buffer containing $10 \mathrm{mmol}^{-1}$ Tris/ $\mathrm{HCl}, 1.5 \mathrm{mmol}^{-1} \mathrm{MgCl}_{2}, 50 \mathrm{mmol}^{-1} \mathrm{KCl}, \mathrm{pH} 8 \cdot 3,200 \mathrm{nmol}^{-1}$ dNTP, 0.5 pmol each primer and Taq DNA polymerase (Boehringer Mannheim). Control PCR with universal primers 616VII and 630R was performed as described previously (Springer et al., 1993).

Generation of random amplified polymorphic DNA (RAPD) patterns. RAPD-PCR was performed in a total volume of $50 \mu \mathrm{l}$. The arbitrary primer used was the universal primer M13V with the following sequence, 5'-GTTTTCCCAGTCACGACGTTG-3'. The reaction mixture contained $20 \mathrm{pmol}^{-1}$ primer, $1.5 \mathrm{U}$ Taq polymerase (Boehringer Mannheim), $5 \mu \mathrm{l}$ Taq polymerase buffer (Boehringer Mannheim), $200 \mathrm{nmol}^{-1}$ each dNTP, $100 \mathrm{ng}$ template DNA and $7 \mu 125 \mathrm{mmol}^{-1} \mathrm{MgCl}_{2}$, resulting in a final concentration of $5 \mathrm{mmol}^{-1} \mathrm{MgCl}_{2}$. Cycling conditions were set as follows: three cycles of $94^{\circ} \mathrm{C}$ for $3 \mathrm{~min}, 40^{\circ} \mathrm{C}$ for $5 \mathrm{~min}$ and $72{ }^{\circ} \mathrm{C}$ for $5 \mathrm{~min}$. This was followed by 32 cycles of $94^{\circ} \mathrm{C}$ for $1 \mathrm{~min}$, $60^{\circ} \mathrm{C}$ for $2 \mathrm{~min}$ and $72{ }^{\circ} \mathrm{C}$ for $3 \mathrm{~min}$. After agarose electrophoresis, patterns were visualized by ethidium bromide staining and documented using a video camera. Images were stored as tiff-files and processed further by GelCompar software version 3.1 (Applied Maths). Cluster analysis was performed by the unweighted pair-group method using arithmetic averages (UPGMA). Correlation levels are expressed using percentage values of the Pearson productmoment coefficient. 
16S rRNA sequence analysis. In vitro amplification of $16 \mathrm{~S}$ rRNA genes and direct sequencing of the amplified $16 \mathrm{~S}$ rDNA fragments were carried out as described previously (Springer et al., 1993). The strains and sequence accession numbers used for the calculations were as follows (for sequences that are not present in the GenBank database, the Ribosomal Database Project code is given): Oceanospirillum commune ATCC 27118, 686; Oceanospirillum jannaschii ATCC 27135 ${ }^{\mathrm{T}}$, 682; Oceanospirillum linum ATCC 11336, M22365; Oceanospirillum beijerinckii ATCC 12754 ${ }^{\mathrm{T}}, 678$, M34133; Oceanospirillum japonicum ATCC 19191 ${ }^{\mathrm{T}}, 661$; Oceanospirillum minutulum ATCC 19193', 662; Pseudomonas aeruginosa ATCC 25330, Zymobacter palmae ATCC 51621, D14555; Halomonas marina ATCC 25374 ${ }^{\mathrm{T}}$, M93354; Halomonas elongata ATCC 33173' ${ }^{\mathrm{T}}$, M93355; Halomonas halmophila ATCC 19717 ${ }^{\mathrm{T}}$, M59153; Halomonas halophila DSM 4770, M93353; Halomonas halodurans DSM 5160, L42619; Halomonas aquamarina DSM 30161 ${ }^{\mathrm{T}}$, M93352; Chromohalobacter marismortui ATCC $17056^{\mathrm{T}}$, X87219.

Analysis of sequence data. The newly determined 16S rRNA primary structure was added to an alignment of more than 6000 homologous bacterial sequences. Sequence analysis was performed with the ARB software package (Ludwig \& Strunk, 1996) For the determination of similarity values, all positions were included, except those of uncertain positions. The construction of the phylogenetic tree was based on a maximum-likelihood analysis as implemented in the program fastDNAml (Maidak et al., 1996) using a subset of 16S rRNA sequences of Proteobacteria, including selected members of the $\gamma$ subclass of the Proteobacteria. Only sequences of at least $90 \%$ completeness were included. Positions that are not shared by individual residues in at least $50 \%$ of sequences were omitted. The topology of the tree was evaluated and corrected according to the results obtained by distance matrix and parsimony analyses based on nearly 10000 sequences (Van den Peer et al., 1994).

Evaluation of pathogenicity. The strain $\mathrm{CTCBS1}^{\mathrm{T}}$ was tested for pathogenicity in male mice weighing $25-30 \mathrm{~g}$, using three pathogenic strains isolated from clinical sources. The bacterial strains used as controls were Escherichia coli HM-42, Pseudomonas aeruginosa HS-1 16 and Staphylococcus aureus HS-93. To establish the lethal doses, six lots of mice (60 mice per bacterial strain) were injected intraperitoneally with concentrated and serially diluted suspensions of the cultured strains. The survival of mice was controlled for up to $8 \mathrm{~d}$.

Scanning electron microscopy. For examination by scanning electron microscope (Zeiss DSM960A), samples were fixed in a solution containing $2.5 \%$ glutaraldehyde, $0.1 \mathrm{~mol}^{-1}$ cacodylate buffer followed by $1 \% \mathrm{OsO}_{4}$ in the same buffer. The samples were processed through a series of ethanol solutions $(50,70,90$ and $100 \%)$, dried by $\mathrm{CO}_{2}$ critical point and coated with gold.

\section{RESULTS}

\section{Morphological characteristics}

On tryptone soya agar, colonies of all of the nine strains CTCBS1 ${ }^{\mathrm{T}}$ to CTCBS9 appeared white, convex, shiny and circular. No pigmentations were visible in any culture medium. All strains were Gram-negative, straight or slightly curved rods, $0.5-0.6 \mu \mathrm{m}$ in width and $1 \cdot 0-1.7 \mu \mathrm{m}$ in length, occurring singly or as pairs. Fig. 1 shows a scanning electron microscopic picture

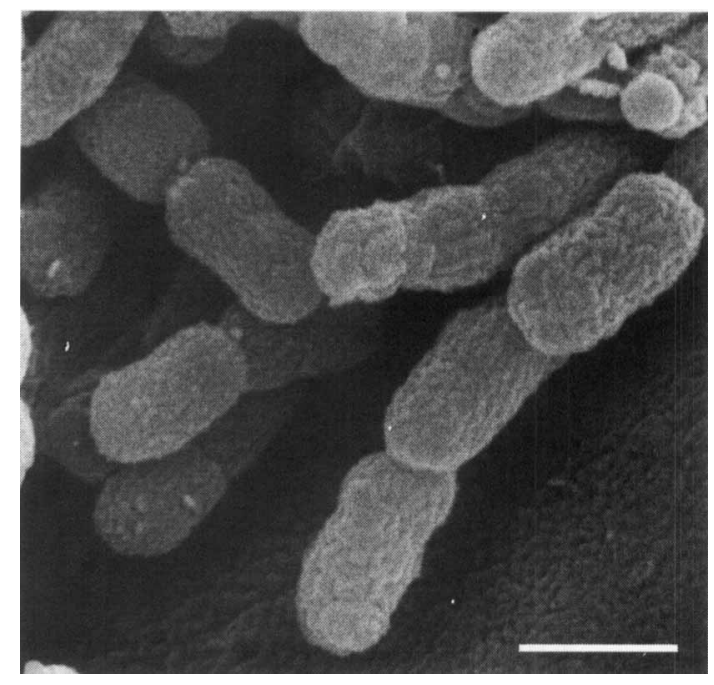

Fig. 1. Scanning electron micrograph of Carnimonas nigrificans strain CTCBS1 $1^{\top}$. Bar, $758 \mathrm{~nm}$.

of strain CTCBS1 $1^{\mathrm{T}}$. Cells were not motile, and spores could not be detected.

\section{Physiological characteristics}

The physiological characteristics of strain CTCBS1 ${ }^{\mathrm{T}}$ were as follows: cells are obligately aerobic. No gas is produced from glucose. Optimum temperature for growth is $28-30{ }^{\circ} \mathrm{C}$. No growth occurs at 5 or $37^{\circ} \mathrm{C}$. Growth occurs in the presence of up to $8 \%$ sodium chloride. Oxidase and catalase activity were positive; indole production, reduction of nitrate and VogesProskauer were negative. Neither urease nor lecithinase activity were detected. Starch and aesculin were hydrolysed; casein, gelatin and DNA were not decomposed. All strains produced acid from glucose, xylose, melibiose, maltose and saccharose. Growth occurs on MacConkey agar and cetrimide agar but not on SS agar. Additional physiological data are provided in Table 1.

\section{Biochemical characterization}

Biochemical tests were performed with strain $\mathrm{CTCBS1}^{\mathrm{T}}$. The main component of respiratory quinones was menaquinone 9 . The main components in the polar lipid composition were diphosphatidylglycerine, phosphatidylglycerine and phosphatidylethanolamine. In addition, there were three unidentified components.

The fatty acid profile contained major amounts of several saturated and unsaturated straight-chain fatty acids and only minor fractions of 3-hydroxylated fatty acids. The main fatty acids were palmitic acid (16:0) with $40 \%$ and the cyclopropanic acid 19:0cyc that occurred at the high level of $21.07 \%$. Oleic acid 18:1 trans 9 occurred at the rate of $7.45 \%$ in addition 
Table 1. Differential characteristics between Carnimonas nigrificans $\mathrm{CTCBS1}{ }^{\top}$ (CECT 4437) and Z. palmae ATCC $51623^{\top}$

\begin{tabular}{|c|c|c|}
\hline Characteristic & C. nigrificans $\dagger$ & Z. palmae \\
\hline Morphology & Short rod & Short rod \\
\hline Cell length $(\mu \mathrm{m})$ & $1.0-1.7$ & $1 \cdot 3-2 \cdot 4$ \\
\hline Cell width $(\mu \mathrm{m})$ & $0.5-0.6$ & $0 \cdot 7-0 \cdot 9$ \\
\hline Gram reaction & Negative & Negative \\
\hline Motility & - & + \\
\hline Flagella & - & Peritrichous \\
\hline Chromogenicity & - & - \\
\hline Relation to oxygen & Strictly aerobic & Facultative anaerobic \\
\hline Growth at $37^{\circ} \mathrm{C}$ & - & + \\
\hline \multicolumn{3}{|l|}{ Hydrolysis of: } \\
\hline Aesculin & + & ND \\
\hline Gelatin & - & - \\
\hline Casein & - & - \\
\hline Starch & + & - \\
\hline Tween 80 & - & ND \\
\hline \multicolumn{3}{|l|}{ Acid production from: } \\
\hline Amygdalin & $+(3 / 9)$ & ND \\
\hline L-Arabinose & $-(0 / 9)$ & - \\
\hline Aesculin & $+(9 / 9)$ & ND \\
\hline Fructose & $+(7 / 9)$ & + \\
\hline Galactose & $\mathrm{w}(9 / 9)$ & + \\
\hline Glucose & $+(9 / 9)$ & + \\
\hline Mannose & $+(7 / 9)$ & - \\
\hline Mannitol & $+(7 / 9)$ & + \\
\hline Melibiose & $+(9 / 9)$ & + \\
\hline Melezitose & $-(2 / 9)$ & ND \\
\hline Raffinose & $w(3 / 9)$ & + \\
\hline Ribose & w (4/9) & ND \\
\hline Saccharose & $+(9 / 9)$ & + \\
\hline Salicin & w $(9 / 9)$ & ND \\
\hline Trehalose & $w(6 / 9)$ & - \\
\hline D-Xylose & $+(9 / 9)$ & - \\
\hline \multicolumn{3}{|l|}{ Utilization of: $\ddagger$} \\
\hline L-Arabinose & - & - \\
\hline Mannose & + & + \\
\hline Mannitol & - & + \\
\hline $\mathrm{N}$-acetylglucosamine & - & ND \\
\hline Maltose & + & + \\
\hline Gluconate & + & ND \\
\hline Caprate & - & ND \\
\hline Adipate & - & ND \\
\hline Malate & - & ND \\
\hline Citrate & + & - \\
\hline Oxidase & + & - \\
\hline Voges-Proskauer & - & + \\
\hline$\beta$-Galactosidase (ONPG) & + & - \\
\hline$\alpha$-Glucosidase (PNPG) & + & + \\
\hline Phenylalanine deaminase & + & - \\
\hline Arginine dihydrolase & - & - \\
\hline Catalase & + & + \\
\hline Nitrate reduction & - & - \\
\hline Urease & - & ND \\
\hline DNase & - & ND \\
\hline Lecithinase & - & ND \\
\hline Production of indole & - & - \\
\hline $\operatorname{Max} .[\mathrm{NaCl}](\mathrm{w} / \mathrm{v})$ & $8-10 \%$ & ND \\
\hline
\end{tabular}

ND, Not determined.

* Data taken from Okamoto et al. (1993).

$\dagger$ Numbers in parentheses indicate the number of strains that showed weak or positive reactions against the number of strains tested.

$\ddagger$ On media containing vitamins and yeast extract. 


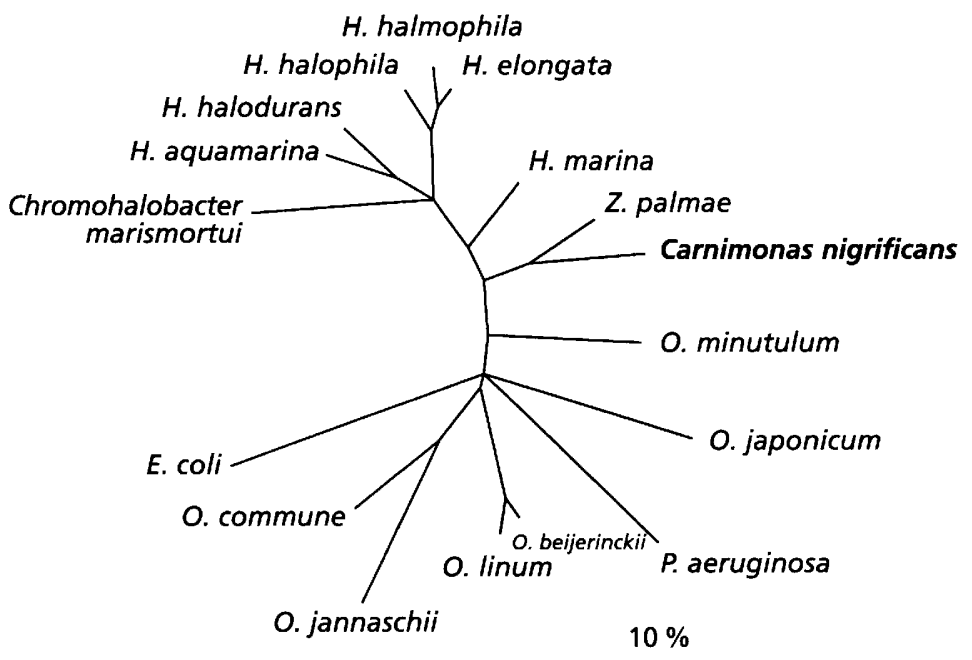

Fig. 2. Phylogenetic relationships of Carnimonas nigrificans strain $\mathrm{CTCBS} 1^{\top}$ and selected representatives of the $\gamma$-subclass of Proteobacteria. The topology of the tree is based on the results of maximum-likelihood analyses and was corrected according to maximum-parsimony and distance methods. The scale bar indicates $10 \%$ estimated substitutions per sequence. with $12.9 \%$ of a summed in feature (18:1 cis $11 /$ trans $9 /$ trans6). Moreover, $16: 1$ could be detected at the $6.7 \%$ level, whereas only minor amounts of 3-OH12:1 (1.85\%) and traces of 3$\mathrm{OH} 16: 0(0.46 \%)$ were found. No match was found after comparison with the TSBA library.

The DNA G + C content of strain CTCBS1 $^{\mathbf{T}}$ analysed by the thermal denaturation method was $56 \cdot 0 \pm 0.3 \mathrm{~mol} \%$.

\section{Phylogenetic relationships}

The $16 \mathrm{~S}$ rDNA sequence of the strain CTCBS1 ${ }^{\mathrm{T}}$ (1519 nucleotides) was determined and deposited in the EMBL database.

Sequence similarity values were in the range 84.4$93.3 \%$ and placed strain CTCBS $^{\mathrm{T}}$ within the $\gamma$ subclass of Proteobacteria. The phylogenetic tree (Fig. 2) shows the closest relationship to Z. palmae ATCC $51623^{\mathrm{T}}$ (sequence similarity of about $93 \cdot 3 \%$ ).

\section{Specific PCR assay}

Comparative sequence analysis of $16 \mathrm{~S}$ rRNA gene sequences revealed a diagnostic sequence that can be used as a target site for specific amplification. Specific amplification of a $480 \mathrm{bp}$ fragment using primer bs 1 and $616 \mathrm{~V}$ occurs only in CTCBS strains (Fig. 4).

Amplification of a $1535 \mathrm{bp}$ fragment occurred in positive controls using primer $616 \mathrm{~V}$ and $630 \mathrm{R}$ in all strains tested, including the reference strains Zymobacter palmae ATCC 51623 ${ }^{\mathrm{T}}$, Pseudomonas fluorescens DSM 50106, Escherichia coli K-12, Enterococcus faecalis DSM 20478, Lactococcus lactis subsp. cremoris DSM 20069 ${ }^{\mathrm{T}}$, Pediococcus damnosus DSM $20331^{\mathrm{T}}$ (Fig. 4).

\section{RAPD patterns}

RAPD-PCR from DNAs of all the organisms tested using M13V primer generated up to 10 distinct bands ranging from 3.3 to $0.55 \mathrm{~kb}$ (Fig. 3a). Most of the bands were of different intensities. The patterns of DNAs of the nine isolates CTCBS $1^{\mathrm{T}}$ to CTCBS9 were very similar and differed only in the presence or absence of bands whose intensities were low.

In general, full reproducibility was given only for those bands whose intensity was high, e.g. the fragments of 3.3 and $0.55 \mathrm{~kb}$ for CTCBS $1^{\mathrm{T}}$. The fingerprints obtained from the reference strains belonging to other genera, Zymobacter palmae ATCC $51623^{\mathrm{T}}$, Pseudomonas aeruginosa DSM 50106 and Escherichia coli K12 , showed bands neither common to each other nor to the meat isolates. From the UPGMA cluster, a high genetic similarity is obvious, as shown in the correlation coefficient of about $80 \%$ (Fig. $3 \mathrm{~b}$ ).

\section{Evaluation of pathogenicity}

After intraperitoneal injection of up to $1.9 \times 10^{10} \mathrm{c} . f . u$. of strain CTCBS1 ${ }^{\mathrm{T}}$, no pathogenic effect was detectable in mice after $8 \mathrm{~d}$. Under the same conditions, bacteria used as controls showed a concentrationdependent lethality. The most pathogenic effect was observed for Escherichia coli HM-42. This organism killed $30 \%$ of mice at $3.5 \times 10^{6}$ c.f.u. and $90 \%$ at $3.5 \times 10^{8}$ c.f.u. No mice survived at $3.5 \times 10^{9}$ c.f.u. In the case of Pseudomonas aeruginosa HS-116, 10\% of mice were killed at $6.3 \times 10^{8}$ c.f.u. and $90 \%$ at $6.3 \times 10^{9}$ c.f.u. The application of $3.7 \times 10^{11}$ c.f.u. of Staphylococcus aureus HS-93 killed $90 \%$ of mice, whereas no pathogenic effect was observed with $3.7 \times 10^{9}$ c.f.u.

\section{DISCUSSION}

One of the problems encountered in the production of raw cured meat products is the occurrence of a rustlike colour on the surface of these products (Hugas \& Arnau, 1987). This defect was found to be caused by the presence of Gram-negative bacteria and shown to be fully reproducible by an inoculation with these organisms (Arnau \& Garriga, 1993). 
(b)

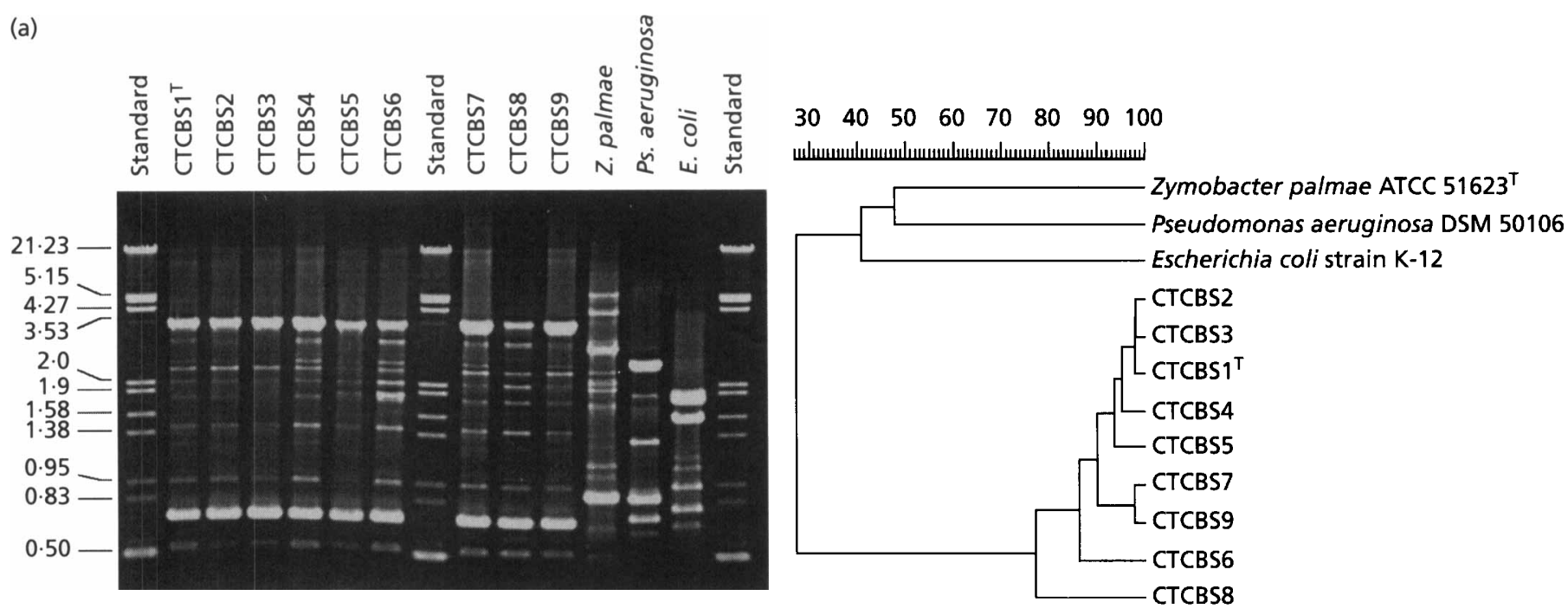

Fig. 3. (a) RAPD fingerprint with M13V primer of Carnimonas nigrificans strains CTCBS1 $1^{\top}$ to $C T C B S 9$, reference organisms Z. palmae ATCC 51623 ${ }^{\top}$, Pseudomonas fluorescens DSM 50106, Escherichia coli strain K-12. Standard molecular mass marker III (Boehringer Mannheim). (b) UPGMA cluster analysis of RAPD patterns from part (a) of Carnimonas nigrificans strains CTCBS1 ${ }^{\top}$ to CTCBS9, reference organisms Z. palmae ATCC $51623^{\top}$, Pseudomonas fluorescens DSM 50106, Escherichia coli strain K-12. Correlation levels are expressed using percentage values of the Pearson product-moment coefficient.

In this paper, nine different isolates were investigated according to their physiological and biochemical characteristics to clarify their phylogenetic positions.

The cells are non-spore-forming, straight or slightly curved, Gram-negative rods, oxidase- and catalasepositive. Their colonies on tryptone soya agar were not pigmented. All strains were obligately aerobic, and their optimum temperature for growth was $28-30{ }^{\circ} \mathrm{C}$. They grew well on cetrimide agar, which is selective for Pseudomonas aeruginosa, but also in MacConkey agar, which is selective for coliform organisms. The strains were not able to grow at 5,37 or $41^{\circ} \mathrm{C}$ or in SS agar. Despite some differences regarding the use of carbohydrates, e.g. ribose, fructose and mannose, a high genetic uniformity of the nine strains was demonstrated when using the M13 primer for a RAPD-PCR analysis. RAPD has already been evaluated as a potential tool for the differentiation of individual strains within certain species belonging to the $\gamma$ subclass of the Proteobacteria (Aznar et al., 1993; Martin-Kearley et al., 1994). However, its differential power for species, strains or even lower clearly depends on the primer used or the combination of results obtained with various primers (Parent et al., 1996). In this investigation, when the M13 primer was applied, a differentiation from other species could easily be achieved at a correlation value of less than $30 \%$, whereas within the nine isolates highly similar patterns were observed (Fig. 3). The small differences proved not to be reproducible and, hence, it is likely that, in this case, a reliable differentiation at strain level needs the choice of additional primers.
The topology of all organisms illustrated in the tree based on maximum-likelihood analysis of 16S rRNA sequences (Fig. 2) is consistent with that in a tree published by Dobson \& Franzmann (1996). The closest relatives of strain $\mathrm{CTCBS}^{\mathrm{T}}$ were $Z$. palmae with $93.3 \%$ sequence similarity and, to a lesser extent, species of the genus Halomonas (at least $91.9 \%$ ) and Chromohalobacter $(91.5 \%)$.

The physiological data indicated, in agreement with the results of chemotaxonomical data discussed later, that these organisms belonged to the $\gamma$-subclass of the Proteobacteria. The 16S rRNA sequence analysis placed these organisms in the $\gamma-3$ subclass of the Proteobacteria, which includes the fluorescent pseudomonads, the genera Oceanospirillum, Chromohalobacter and Marinobacter (Gauthier et al., 1992; Gosink \& Stanley, 1995), as well as all genera of the family Halomonadaceae (Dobson et al., 1993; Franzmann et al., 1988). They formed a genetically homogeneous group, which is phylogenetically distinct from all other organisms actually present in the mentioned taxa. All data presented here support the status of strains CTCBS1 ${ }^{\mathrm{T}}$ to CTCBS9 belonging in a new genus, for which we propose the name Carnimonas due to their source of isolation.

Owing to their genetic homogeneity, the nine strains CTCBS1 $^{\mathrm{T}}$ to CTCBS9 should be combined into one species named Carnimonas nigrificans. This name reflects their blackening effect on meat products.

At present, DNA-DNA hybridization data for Halomonadaceae and related genera are limited. More- 
Table 2. Differential characteristics of strain $\mathrm{CTCBS}^{\top}$ and the genera Oceanospirillum and genera belonging to the family Halomonadaceae

Data from this study and Ventosa et al. (1989), Franzmann \& Tindall (1990), Okamoto et al. (1993) and Sakane \& Yokota (1994).

\begin{tabular}{|c|c|c|c|c|c|}
\hline \multirow[t]{2}{*}{ Characteristic } & \multirow[t]{2}{*}{ CTCBS1 $^{\mathrm{T}}$} & \multicolumn{3}{|c|}{ Family Halomonadaceae: } & \multirow[t]{2}{*}{ Oceanospirillum } \\
\hline & & Halomonas & Chromohalobacter & Zymobacter & \\
\hline $\mathrm{G}+\mathrm{C}$ content $(\mathrm{mol} \%)$ & $56 \pm 0 \cdot 3$ & $60 \cdot 5-66 \cdot 7$ & $62-64 \cdot 9$ & $55 \cdot 4-56 \cdot 2$ & $42-51$ \\
\hline Major respiratory lipochinone & Ubiquinone 9 & Ubiquinone 9 & ND & Ubiquinone 9 & Ubiquinone 8 \\
\hline $\begin{array}{l}\text { Number of } 16 \mathrm{~S} \text { rRNA signature } \\
\text { characteristics shared with } \\
\text { Halomonas }\end{array}$ & 13 & 19 & 19 & 15 & 10 \\
\hline Pigments & None & White/yellow & Yellow/blue & None & None* \\
\hline Major non-polar fatty acids & $\begin{array}{l}16: 0,16: 1, \\
18: 1 \dagger, 19 \text { cyc }\end{array}$ & $\begin{array}{l}16: 0,16: 1 \\
17 \text { cyc, } 18: 1 \dagger \\
19 \text { cyc }\end{array}$ & ND & $\begin{array}{l}12: 0,16: 0 \\
18: 0 \\
18: 1,19 \text { cyc }\end{array}$ & $16: 0,16: 1,18: 0$ \\
\hline Motility & - & $\mathrm{D}$ & + & + & + \\
\hline Flagella & None & Peritrichous/polar & Peritrichous & Peritrichous & Polar \\
\hline Max. $[\mathrm{NaCl}](\%)$ & 8 & $32 \cdot 5$ & $>30$ & ND & $9 \cdot 75$ \\
\hline Relation to oxygen & Aerobic & Aerobic $\ddagger$ & Aerobic & Fac. anaerobic & Aerobic \\
\hline Oxidase & + & $\mathrm{D}$ & - & - & + \\
\hline
\end{tabular}

ND, Not determined; D, different.

* Some strains produces a water-soluble, yellow-green fluorescent pigment on PSS seawater agar.

† Summed feature containing 18:1, cis 11 , trans 9 and trans6.

$¥$ Some strains are capable of anaerobic growth in the presence of nitrate.

over, it has already been shown that it is unlikely that two species exhibiting less than $99 \%$ 16S rRNA sequence similarity would have a DNA-DNA hybridization value of $\geqslant 70 \%$, this being the criterion for delineating species (Amann et al., 1992; Fox et al., 1992). The level of sequence similarity between Halomonas euryhalina and Halomonas elongata is 99.1\% (Dobson et al., 1996) and the level of DNADNA hybridization is only $7 \%$ (Valderama et al., 1991). As 16S rRNA sequence similarity values of strain CTCBS $1^{\mathrm{T}}$ to all other organisms does not exceed $93.3 \%$, no DNA-DNA hybridization data are provided.

In contrast to the species definition, there is no widely accepted level of phylogenetic relationship for defining bacterial genera expressed in concrete values of DNADNA hybridization or sequence similarity (Wayne et al., 1987; Stackebrandt, 1992). Therefore, the delineation of genera solely on the basis of phylogenetic data is completely impracticable (Murray et al., 1990).

The description of a new taxon requires not only that a group of organisms be phylogenetically homogeneous as inferred from genotypic data, but that there be chemotaxonomic or phenotypic features characteristic of the group that differentiate it from closely related genera. Likewise, in Table 2, there were sufficient phenotypical differences to support the assignment of strains CTCBS $1^{\mathrm{T}}$ to CTCBS9 to a new taxon at genus level.
The $\mathrm{G}+\mathrm{C}$ content of $56 \mathrm{~mol} \%$, major respiratory lipochinone and the lack of C19cyc in the non-polar lipid profile are sufficient to exclude these organisms from Oceanospirillum.

The recent unification of the genera Deleya, Halomonas and Halovibrio into the single genus Halomonas arose from the realization that a couple of phenotypic features failed to delineate phylogenetically meaningful taxa within these organisms (Dobson et al., 1996). In fact, in this case, differences in fatty acid profiles, major respiratory lipochinones and $\mathrm{G}+\mathrm{C}$ contents are too small to delineate different subgroups. On the other hand, criteria such as morphology, salt tolerance, motility and oxidase were found to be too diverse within these organisms and, hence, more useful for describing species than genera (Dobson et al., 1996). Nevertheless, these criteria become more useful when comparing taxa that are phylogenetically distinct at a lower level.

The $\mathrm{G}+\mathrm{C}$ content of Halomonas and Chromohalobacter differs by at least $4.2 \mathrm{~mol} \%$ from strain CTCBS1 ${ }^{\mathrm{T}}$, and distinct differences in the fatty acid profile were as follows. The levels of 16:0 in the profiles of members of the genus Halomonas range from $15 \cdot 5$ to $32 \%$, whereas the level in CTCBS1 ${ }^{\mathrm{T}}$ is $40 \%$. Additionally, in contrast to Halomonas, in $\mathrm{CTCBS1}^{\mathrm{T}}$ no 17 cyc could be detected. Even if conversion of monosaturated fatty acids to its cyclopropane derivative is sensitive to culture conditions 
Table 3. 16S rRNA sequence signature characteristics of the genus Halomonas which are different from Zymobacter and/or Carnominas nigrificans strain CTCBS $1^{\top}$

Data for Halomonas are from Dobson et al. (1996). Positions are according to the Escherichia coli numbering system.

\begin{tabular}{|c|c|c|c|}
\hline Position & Halomonas & Zymobacter & Carnimonas \\
\hline $76-93$ & 6 bp stem & 6 bp stem & 6 bp stem \\
\hline 484 & A & A & $\mathbf{G}$ \\
\hline 486 & C & $\mathrm{C}$ & $\mathbf{u}$ \\
\hline 640 & G & G & $\mathbf{G}$ \\
\hline 660 & A & A & A \\
\hline 668 & A & A & A \\
\hline 669 & A & A & A \\
\hline 737 & $U$ & $\mathrm{U}$ & $\mathrm{U}$ \\
\hline 738 & $\mathrm{U}$ & $U$ & $\mathrm{U}$ \\
\hline 745 & $U$ & $U$ & $\mathrm{U}$ \\
\hline 776 & U & $U$ & U \\
\hline 1124 & U & $\mathrm{U}$ & U \\
\hline 1297 & $U$ & U & $U$ \\
\hline 1298 & C & C & C \\
\hline 1423 & A & A & A \\
\hline 1424 & C & U & $\mathrm{U}$ \\
\hline 1439 & U & C & C \\
\hline 1462 & A & C & C \\
\hline 1464 & $\mathrm{C}$ & $U$ & C \\
\hline
\end{tabular}

and the addition of $16: 0$ plus 17 cyc may be a more stable characteristic (Jantzen \& Bryn, 1985), the difference remained significant $\left(\mathrm{CTCBS1} \mathrm{1}^{\mathrm{T}}\right.$ about $6.7 \%$ and Halomonas $7 \cdot 7-43 \cdot 1 \%$ ). No difference was found in their major respiratory lipochinone, which is ubiquinone 9 in the case of Halomonas and Zymobacter. Unfortunately, in the case of members of Chromohalobacter, neither lipid profile nor respiratory lipochinone data exist, although they can easily be distinguished by their production of pigments (Ventosa $e t$ al., 1989).

$Z$. palmae is the single species of the genus Zymobacter and the closest phylogenetic relative to strain CTCBS1 $^{\mathrm{T}}$ (Okamoto et al., 1993). Moreover, the greatest chemotaxonomic similarity to $\mathrm{CTCBS}^{\mathrm{T}}$ is shown in this case. The $\mathrm{G}+\mathrm{C}$ content of its DNA is $55.8 \mathrm{~mol} \%$, which is within the range determined for $\mathrm{CTCBS1}^{\mathrm{T}}$. Their profiles of the major fatty acids are similar; however, a significant amount of 12:0 (5\%), which might be unique to $Z$. palmae, was not detected in strain $\mathrm{CTCBS1}^{\mathrm{T}}$ or in the other closely related genera. In addition, some physiological and morphological properties, e.g. relationship to oxygen, growth temperature, hydrolysis of starch, oxidase reaction as well as flagellation and motility, are useful in differentiating between these two organisms.

A common characteristic of all the genera mentioned in this study is their more or less pronounced salt requirement or tolerance, which is explicable by their isolation from saline environments, including the surface of cured meat products, from which strains CTCBS $^{\mathrm{T}}-9$ were isolated. CTCBS $1^{\mathrm{T}}$ growth is optimal at $4 \% \mathrm{NaCl}$ and inhibited at $8 \% \mathrm{NaCl}$. To our knowledge, no study has been conducted on the salt tolerance of $Z$. palmae, but high osmotolerance has been shown by the fact that it can grow in the presence of $50 \%$ maltose (Okamoto et al., 1993).

At present, the family Halomonadaceae is based on a pattern or core of phenotypical characteristics that would also be shared by strain CTCBS1 ${ }^{\mathrm{T}}$. However, this grouping is not supported by phylogenetic data. In the emendation of the family Halomonadaceae, $Z$. palmae was included as a member of this family mainly because of the common occurrence of signature characteristics in its 16S rRNA sequence (Dobson \& Franzmann, 1996). To achieve this, the number of diagnostic signature characteristics was reduced from 19 to 15 , which are retained as descriptive characteristics of the members of the family Halomonadaceae.

Although strain $\mathrm{CTCBS}^{\mathrm{T}}$ and $Z$. palmae actually form a monophyletic group, it shares only 13 of 15 signatures defining the family Halomonadaceae. As detailed in Table 3 , these substitutions were at position 484 and position 486 , at which an adenine is replaced by a guanine and a rare cytosine is replaced by guanine, respectively. Furthermore, these positions are within the region used successfully in this study as a diagnostic sequence for a specific identification and differentiation by a PCR assay (Fig. 4).

As both Zymobacter and the newly described genus Carnimonas are genera containing one species up to now, we propose to avoid a hasty change of the family description that would necessarily include a further reduction in the signature sequences from 15 to 13 and, hence, not to include Carnimonas before more species are found.

All newly described strains were isolated from cured meat products. Therefore, strain $\mathrm{CTCBS1}^{\mathrm{T}}$ was subjected to toxicological studies. No pathogenic potential of the strain CTCBS $1^{\mathrm{T}}$ was determined compared with the three reference strains assayed.

As these organisms were not pigmented and no pigments were released in the culture media, the visible colouration on meat seems rather to be a non-enzymic browning reaction of special components derived from the meat surface. The chemical mechanism has not yet been elucidated but, as far as we know, some sugars and/or specific amino acids are involved (Arnau \& Garriga, 1993).

\section{Description of Carnimonas gen. nov.}

Carnimonas (Car.ni'mo.nas. L. gen. n. carnis of meat; Gr. n. monas a unit, monad).

Non-spore-forming, Gram-negative, straight or slightly curved rod, occurring singly or as pairs, non- 


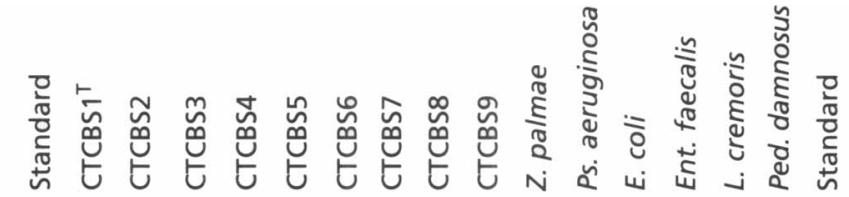

(a)

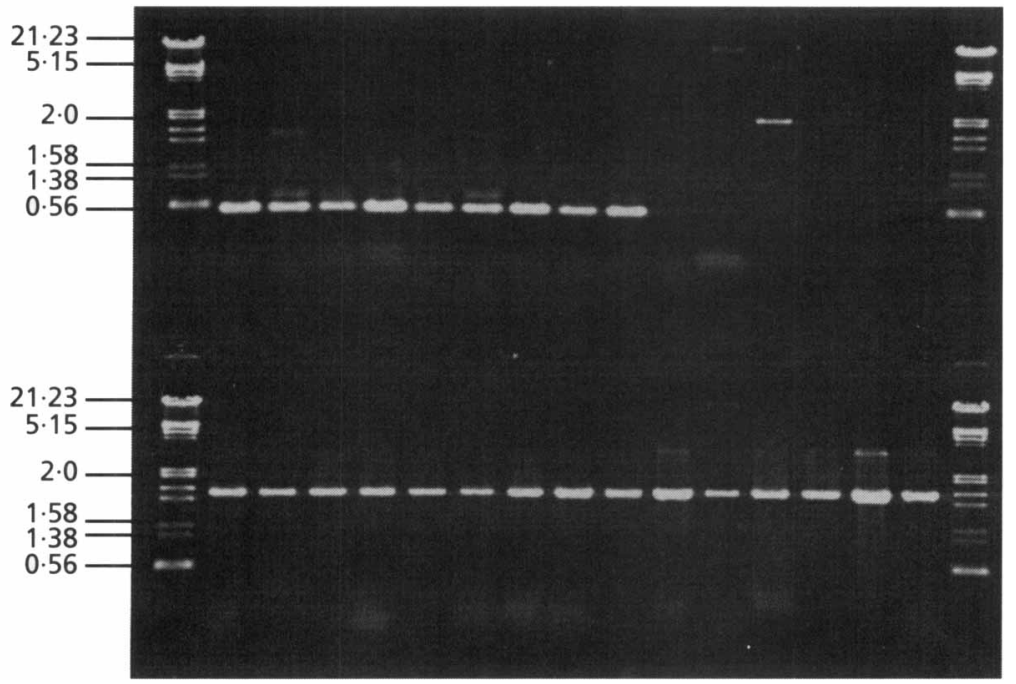

Fig. 4. Specific PCR assay for identification of the newly described Carnimonas nigrificans strains, reference organisms $Z$. palmae ATCC 51623', Pseudomonas fluorescens DSM 50106, Escherichia coli strain K-12, Enterococcus faecalis DSM 20478; Lactococcus lactis subsp. cremoris DSM 20069', Pediococcus damnosus DSM 20331 ${ }^{\top}$. S, Molecular mass marker III (Boehringer Mannheim). (a) The specific PCR using primer bs 1 and universal primer $97 \mathrm{~K}$ resulting in a $480 \mathrm{bp}$ fragment. (b) To exclude false-negatives, a PCR was performed using universal primers $616 \mathrm{~V}$ and 630R, resulting in a 1535 bp fragment. motile, oxidase and catalase activity positive. Cells are obligately aerobic and slightly or moderate halophile. No growth occurs in the presence of more than $8 \%$ $\mathrm{NaCl}$. Optimum temperature for growth is $28-30^{\circ} \mathrm{C}$. No growth occurs at 5 or $37^{\circ} \mathrm{C}$. Chemoorganotrophic. The main component of respiratory quinones is ubiquinone 9 . The main components in the polar lipid composition are diphosphatidylglycerine, phosphatidylglycerine and phosphatidylethanolamine. The major fatty acids are 16:0,16:1, 18:1 plus 19 cyc. The type species is Carnimonas nigrificans.

\section{Description of Carnimonas nigrificans sp. nov.}

Carnimonas nigrificans (nig.rif'i.cans. L. adj. niger black; L. v. facere to make; L. n. nigrificans blackmaking).

The description of the species corresponds to that of the genus. Additional characteristics are given as follows. Colonies are non-pigmented, white, convex, shiny and circular. Acid is produced from glucose, fructose, maltose, xylose, melibiose and saccharose. Aesculin and starch are hydrolysed. Gelatin, casein and DNA are not hydrolysed. Voges-Proskauer negative. Arginine dihydrolase, urease, lecithinase and phenylalanine deaminase negative. Indole is not produced. Nitrate is not reduced. Strain CTCBS1 ${ }^{\mathrm{T}}$ $\left(\mathrm{CECT} 4437^{\mathrm{T}}\right)$ is the type strain.

\section{ACKNOWLEDGEMENTS}

We thank Wolfgang Ludwig (Lehrstuhl für Mikrobiologie, Technische Universität München) for his help in sequence analysis and tree construction. We also thank Christine Luginger for her excellent technical assistance.

\section{REFERENCES}

Amann, R. I., Lin, C., Key, R., Montgomery, L. \& Stahl, D. (1992). Diversity among Fibrobacter isolates: towards a phylogenetic classification. Syst Appl Microbiol 15, 23-31.

Arnau, J. \& Garriga, M. (1993). Black spot in cured meat products. Fleischwirtschaft 73, 1393-1394.

Aznar, R., Ludwig, W. \& Schleifer, K. H. (1993). Ribotyping and randomly amplified polymorphic DNA analysis of Vibrio vulnificus biotypes. Syst Appl Microbiol 16, 303-309.

Deley, J. (1970). Re-examination of the association between melting point, buoyant density, and chemical base composition of deoxyribonucleic acid composition. J Bacteriol 101, 738-754.

Dobson, S. J. \& Franzmann, P. D. (1996). Unification of the genera Deleya (Baumann et al. 1983), Halomonas (Vreeland et al. 1980), and Halovibrio (Fendrich 1988) and the species Paracoccus halodenitrificans (Robinson and Gibbons 1952) into a single genus, Halomonas, and placement of the genus Zymobacter in the family Halomonadaceae. Int J Syst Bacteriol 46, 550-558.

Dobson, S. J., McMeekin, T. A. \& Franzmann, P. D. (1993). Phylogenetic relationships between some members of the genera Deleya, Halomonas, and Halovibrio. Int J Syst Bacteriol 43, 665-673.

Fox, G. E., Wisotzkey, J. D. \& Jurtschuk, P., Jr (1992). How close is close: 16S rRNA sequence identity may not be sufficient to guarantee species identity. Int J Syst Bacteriol 42, 166-170.

Franzmann, P. D. \& Tindall, B. J. (1990). A chemotaxonomic study of the family Halomonadaceae. Syst Appl Microbiol 13, 142-147.

Franzmann, P. D., Burton, H. R. \& McMeekin, T. A. (1987). Halomonas subglaciescola, a new species of halotolerant bacteria isolated from Antarctica. Int J Syst Bacteriol 37,27-34.

Franzmann, P. D., Wehmeyer, U. \& Stackebrandt, E. (1988). Halomonadaceae fam. nov. A new family of the class Proteobacteria to accommodate the genera Halomonas and Deleya. Syst Appl Microbiol 11, 16-19. 
Gauthier, M. J., Lafay, B., Christen, R., Fernandez, L., Acvaviva, M., Bonn, P. \& Bertrand, J. C. (1992). Marinobacter hydrocarbonoclastius, new genus new species: a new, extremely halotolerant, hydrocarbon-degrading marine bacterium. Int $J$ Syst Bacteriol 42, 568-576.

Gill, C. O. \& Lowry, P. D. (1982). Growth at sub-zero temperatures of black spot fungi from meat. J Appl Bacteriol 52, 245-50.

Gosink, J. J. \& Staley, J. T. (1995). Biodiversity of gas vacuolate bacteria from Antarctic sea ice and water. Appl Environ Microbiol 61, 3486-3489.

Hugas, M. \& Arnau, J. (1987). Aparición de manchas de color marrón en la corteza y grasa del jamón durante el post-salado. In Jamón Curado. Aspectos Técnicos, pp. 179-182. Edited by J. Arnau, M. Hugas \& J. M. Monfort. Monells, Spain: Institut de Recerca i Tecnología Agroalimentáries.

Huss, V. A. R., Festl, H. \& Schleifer, K. H. (1983). Studies on the spectrophotometric determination of DNA hybridization from renaturation rates. Syst Appl Microbiol 4, 184-192.

Jantzen, E. \& Bryn, K. (1985). Whole-cell and lipopolysaccharide fatty acids and sugars of Gram-negative bacteria. In Chemical Methods in Bacterial Systematics, pp. 145-172. Edited by M. Goodfellow and D. E. Minnikin. London: Academic Press.

Lewington, J., Greenaway, S. P. \& Spillane, G. J. (1987). Rapid small scale preparation of bacterial genomic DNA, suitable for cloning and hybridization analysis. Lett Appl Microbiol 5, 51-53.

Ludwig, W. \& Strunk, O. (1996). ARB, a software environment for sequence data. http://www.mikro.biologie.tumuenchen.de/pub/ARB/documentation.

Maidak, B. L., Olsen, G. J., Larsen, N., Overbeek, R., McCaughey, M. J. \& Woese, C. R. (1996). The Ribosomal Database Project (RDP). Nucleic Acids Res 24, 82-85.

Marmur, J. (1961). A procedure for the isolation of deoxyribonucleic acid from microorganisms. $J$ Mol Biol 3, 208-218.

Martin-Kearley, J., Gow, J. A., Peloquin, M. \& Greer, C. W. (1994). Numerical analysis and the application of random amplified polymorphic DNA polymerase chain reaction to the differentiation of Vibrio strains from a seasonally cold ocean. Can $J$ Microbiol 40, 446-455.

Minnikin, D. E., Collins, M. D. \& Goodfellow, M. (1977). Fatty acid and polar lipid composition in the classification of Cellulomonas, Oerskovia, and related taxa. J Appl Bacteriol 47, 87-95.

Murray, R. G. E., Brenner, D. J., Colwell, R. R., De Vos, P., Goodfellow, M., Grimont, P. A. D., Pfennig, N., Stackebrandt, E. \& Zavarin, G. A. (1990). International Committee on Systematic Bacteriology. Report of the ad hoc committee on approaches to taxonomy within the Proteobacteria. Int J Syst Bacteriol 40, 213-215.

Norton, C. F. \& Jones, G. E. (1969). A marine isolate of Pseudomonas nigrifaciens. Arch Microbiol 6, 369-376.
Okamoto, T., Taguchi, H., Nakamura, K., Ikenaga, H., Kuraishi, H. \& Yamasato, K. (1993). Zymobacter palmae gen. nov., a new ethanol-fermenting peritrichous bacterium isolated from palm sap. Arch Microbiol 160, 333-338.

Parent, J. G., Lacroix, M., Page, M. D., Vezina, L. \& Vegiard, S. (1996). Identification of Erwinia carotovora from soft rot diseased plants by random amplified polymorphic (RAPD) DNA analysis. Mol Gen Genet 239, 17-27.

Prusky, D., Gat, Z. \& Burd, P. (1993). Effect of relative humidity during mango growth on the incidence of quiescent infections of Alternaria alternata. Plant Dis 77, 249-252.

Read, P. J. (1991). The susceptibility of tubers of potato cultivars to black dot (Colletotrichum coccodes (Wallr.) Hughes). Ann Appl Biol 119, 475-482.

Sakane, T. \& Yokota, A. (1994). Chemotaxonomic investigation of heterotrophic, aerobic and microaerophilic spirilla, the genera Aquaspirillum, Magnetospirillum and Oceanospirillum. Syst Appl Microbiol 17, 128-134.

Sneath, P. H. A. (1984). Genus Chromobacterium. In Bergey's Manual of Systematic Bacteriology, vol. 1, pp. 580-582. Edited by N. R. Krieg \& J. G. Holt. Baltimore: Williams \& Wilkins.

Springer, N., Ludwig, W., Amann, R., Schmidt, H. J., Görtz, H. D. \& Schleifer, K. H. (1993). Occurrence of fragmented 16S rRNA in an obligate bacterial endosymbiont of Paramecium caudatum. Proc Natl Acad Sci USA 90, 9892-9895.

Stackebrandt, E. (1992). Unifying phylogeny and phenotypic diversity. In The Prokaryotes. A Handbook on the Biology of Bacteria: Ecophysiology, Isolation, Identification, Applications, 2nd edn, vol. 1, pp. 19-47. Edited by A. Balows, H. G. Trüper, M. Dworkin, W. Harder \& K. H. Schleifer. New York: Springer.

Starr, M. P. (1958). The blue pigment of Corynebacterium insidiosum. Arch Microbiol 30, 325-334.

Tindall, B. J. (1990). Lipid composition of Halobacterium lacusprofundi. FEMS Microbiol Lett 66, 199-202.

Valderrama, M. J., Quesada, E., Béjar, V., Ventosa, A., Gutierrez, M. C., Ruiz-Berraquero, F. \& Ramos-Cormenzana, A. (1991). Deleya salina sp. nov., a moderately halophilic gram-negative bacterium. Int J Syst Bacteriol 41, 377-384.

Van den Peer, Y., Van den Broeck, I., De Rijk, P. \& De Wachter, R. (1994). Database on the structure of small ribosomal subunit RNA. Nucleic Acids Res 22, 3488-3494.

Ventosa, A., Gutiererez, M. C., Garcia, M. T. \& Ruiz-Berraquero, F. (1989). Classification of 'Chromobacterium marismortui' in a new genus, Chromohalobacter gen. nov., as Chromohalobacter marismortui comb. nov., nom. rev. Int J Syst Bacteriol 39, 382-386.

Wayne, L. G., Brenner, D. J., Colwell, R. R. \& 9 other authors (1987). International Committee on Systematic Bacteriology. Report of the ad hoc committee on recognition of approaches to bacterial systematics. Int J Syst Bacteriol 37, 463-464. 